\title{
KEBIJAKAN INVESTASI ASING DALAM PENGEMBANGAN PARIWISATA YANG BERBASIS DESA ADAT DI PROVINSI BALI
}

\author{
Made Sumerti Asih ${ }^{1}$, Nyoman Sri Ratnawati ${ }^{2}$, I Wayan Wirawan ${ }^{3}$ \\ Akademi Pariwisata Denpasar ${ }^{1,2,3}$ \\ sumertiasih58@gmail.com ${ }^{1}$; sriratnawati1703@gmail.com $^{2}$; wayanmebalik@gmail.com ${ }^{3}$
}

\author{
Received: April 12, 2021 | Accepted: May 10, 2021 | Published: May 17, 2021 \\ Permalink/DOI: https://doi.org/10.53356/diparojs.v1i2.35
}

\begin{abstract}
ABSTRAK
Pembangunan di bidang sektor pariwisata membutuhkan dana yang sangat besar, bersumber dari dana Pemerintah, swasta, masyarakat dan penanam modal asing. Indonesia sebagai Negara berkembang sering mengalami kesulitan dana dalam pelaksanaan pembangunan karena sumber dana yang terbatas. Pemerintah perlu merumuskan kebijakan dalam bentuk perundang-undangan serta, reformasi birokrasi sehingga mampu memberikan pelayanan publik yang optimal, serta menarik minat investasi asing agar mempercepat pelaksanaan pembangunan dalam rangka mewujudkan tujuan nasional, yaitu kesejahteraan masyarakat. Secara umum, peraturan tentang penanaman modal termasuk investasi asing telah diatur dalam Undang-Undang Nomor 25 tahun 2007, tentang penanaman modal, Peraturan Presiden Nomor 27 tahun 2009, tentang Pelayanan Terpadu Satu Pintu, serta Peraturan Kepala Badan Koordinasi Penanaman Modal Nomor 14 tahun 2015, tentang Tata Cara dan Prinsip Penanaman Modal, dan Undang-Undang Nomor 23 tahun 2014, tentang Pemerintah Daerah. Pembangunan pariwisata di Bali sangat pesat dengan dibangunnya berbagai jenis fasilitas pariwisata, dan ke depan, untuk menghindari kejenuhan perlu dikembangkan wisata alternatif, seperti Desa Wisata. Ditetapkannya Peraturan Daerah Provinsi Bali Nomor 4 tahun 2019, tentang Desa Adat mempertegas bahwa Desa Adat dapat mengelola Desa wisata.. Keterlibatan investasi asing dalam mengembangkan pariwisata yang bebasis desa adat sangat dimungkinkan, maka Pemerintah Daerah perlu bersama-sama Pemerintah Kabupaten/kota serta Desa Adat berdasarkan kedudukan dan kewenangannya dapat menetapkan peraturan untuk menjamin kepastian hukum bagi investor dan masyarakat dengan tetap berlandaskan pada prinsi-prinsip penyelenggaraan pemerintahan yang baik.
\end{abstract}

Kata kunci : kebijakan, investasi asing, pariwisata berbasis desa adat.

\section{ABSTRACT}

Development in the tourism sector requires enormous funds, sourced from government, private, public and foreign investors funds. Indonesia as a developing country often experiences funding difficulties in the implementation of development due to limited funding sources. The government needs to formulate policies in the form of legislation as well as reform of the bureaucracy so that it is able to provide optimal public services and attract foreign investment in order to accelerate the implementation of development in the context of realizing national goals, namely the welfare of the community. In general, the regulations regarding investment including foreign investment have been regulated in Law Number 
25 of 2007 concerning investment, Presidential Regulation Number 27 of 2009 concerning One Stop Integrated Services and Regulation of the Head of the Investment Coordinating Board Number 14 of 2015 concerning Procedures and Principles. Investment and Law Number 23 of 2014 concerning Regional Government. Tourism development in Bali is very fast with the construction of various types of tourism facilities, and in the future, to avoid burnout, it is necessary to develop alternative tourism such as Tourism Village. The stipulation of the Bali Provincial Regulation Number 4 of 2019 concerning Traditional Villages confirms that Traditional Villages can manage tourism villages. The involvement of foreign investment in developing tourism based on traditional villages is very possible, so the Regional Government needs to work together with Regency / City Governments and Traditional Villages based on their position and authority can stipulate regulations to ensure legal certainty for investors and the public by continuing to be based on the principles of good governance.

Keywords: policy, foreign investment, traditional village-based tourism

\section{PENDAHULUAN}

Pembangunan sektor pariwisata saat ini masih menjadi salah satu pengembangan prioritas oleh pemerintah baik pusat maupun daerah karena dinilai mampu menjadi motor penggerak bagi perekonomian bangsa. Pengembangan sektor pariwisata terus dilakukan pemerintah melalui penetapan berbagai kebijakan karena berkontribusi pada penerimaan devisa, pendapatan daerah, membuka lapangan kerja serta penyerapan investasi dalam pengembangan usaha yang tersebar di wilayah provinsi Bali.

Penanaman modal asing sangat dibutuhkan karena pembangunan pariwisata memerlukan modal/dana yang cukup besar yang bersumber dari Pemerintah, swasta dan masyarakat serta investasi asing. Idealnya dana tersebut dari sisi kebangsaan, kebutuhan akan dana tersebut sepenuhnya dapat disediakan oleh kemampuan modal dalam negeri atau usaha swasta dalam negeri. Namun, tidaklah demikian karena umumnya negara berkembang, seperti Indonesia, dalam melaksanakan pembangunan sering mengalami kesulitan dana yang disebabkan oleh berbagai faktor, antara lain kewajiban membayar pajak masih rendah, kesadaran menabung belum bisa diandalkan akibat pendapatan masyarakat yang rendah, akumulasi modal yang tidak efisien dan efektif, kurangnya kepercayaan investor asing serta ketrampilan memanfaatkan tehnologi belum maksimal.
Dengan pelaksanaan Undang-Undang Nomor 23 tahun 2014 tentang Pemerintah Daerah telah dilakukan reformasi birokrasi penyelenggaraan pemerintahan di daerah, dengan memberikan peran yang lebih besar kepada kabupaten dan kota berdasarkan asas otonomi yang luas untuk ber upaya mewujudkan kesejahteraan masyarakat daerah dan keadilan melalui peningkatan pengelolaan sumber daya dan potensi daerah.

Salah satu upaya yang dapat dilakukan untuk mewujudkan tujuan tersebut adalah melaksanakan pembangunan ekonomi daerah sebagai kelanjutan dari pembangunan ekonomi nasional sesuai dengan amanat dalam UUD 1945. Untuk mempercepat pembangunan ekonomi, khususnya sektor pariwisata dan mewujudkan kedaulatan politik dan ekonomi Indonesia umumnya dan Bali khususnya, diperlukan peningkatan investasi dan/atau penanaman modal yang bersumber baik dari modal dalam negeri maupun dari luar negeri.

Pengaturan mengenai penanaman modal telah ditetapkan dalam Undang Undang Nomor 25 tahun 2007 tentang Penanaman Modal termasuk penanaman modal asing. Penyelenggaraan urusan penanaman modal diatur sebagai berikut:

1. Pemerintah dan/atau Pemerintah Daerah menjamin kepastian dan keamanan berusaha bagi pelaksanaan penanaman modal.

2. Pemerintah Daerah Menyelenggarakan urusan penanaman modal yang menjadi kewenangannya kecuali urusan 
penyelengaraan yang menjadi urusan pemerintah.

3. Penyelenggaraan urusan pemerintahan yang merupakan urusan wajib pemerintah daerah didasarkan pada kreteria eksternalitas,akuntabilitas dan efisiensi pelaksanaan penanaman modal.

4. Penyelenggaraan penanaman modal yang ruang lingkupnya lintas kabupaten/kota menjadi urusan provinsi.

5. Penyelenggaraan penanaman modal yang linngkupnya dalam satu kabupaten/kota menjadi urusan kabupaten/kota.

Dengan ditetapkan kebijakan investasi tersebut, dapat mengatasi faktor penghambat investasi dengan perbaikan koordinasi,antara pemerintah pusat dan daerah,penciptaan birokrasi yang efisien dan efektif, kepastian hukum dan iklim usaha kepariwisataan yang nyaman,karena sesuai dengan sistem hukum investasi diindonesia. Untuk provinsi Bali, realisasi investasi tahun 2019 yang dipatok sebesar 14,8 triliun baru terealisasi 9,7 triliun atau $65,33 \%$. Realisasi yang belum maksimal ini dikarenakan regulasi yang masih banyak tumpang tindih, yang belum ditindak lanjuti oleh pemerintah provinisi dan pemerintah kabupaten/kota yang artinya pemerintah daerah belum mampu memberikan kepastian hukum kepada calon investor asing.

Pemerintah telah melakukan berbagai strategi program pembangunan pariwisata seperti pegembangan pasar wisatawan,pengembangan citra pariwisata,kemitraan pemasaran pariwisata dan promosi pariwisata sebagaimana tertuang dalam RPJMN 2015 -2019 yang menjadikan akselerasi pertumbuhan pariwisata sebagai salah satu akselerasi pertumbuhan ekonomi nasional. Namun akhir 2019 dunia diguncang dengan meluasnya virus baru yang diberi nama covid19 yang telah menjadi pandemik dan sangat berdampak pada sektor perekonomian dunia dan sector pariwisata Indonesia dan bali khususnya.

Pemerintah perlu mengambil langkahlangkah kebijakan alternatif dalam sektor pariwisata dengan menerapkan strategi yang mampu beradaptasi dengan kondisi pandemik baik melalui kebijakan fiskal maupun nonfiskal.Langkah Pemerintah Provinsi Bali dapat melakukan kegiatan pengembangan pariwisata lokal melalui program desa wisata.Pengembangan desa wisata didasarkan adanya potensi yang dimiliki desa dengan aspek pelestarian lingkungan, tradisi yang turun temurun, kebudayaan yang melekat pada masyarakatnya sehingga dengan keterlibatan masyarakat dapat menciptakan iklim pariwisata yang berkelanjutan tidak semata-mata untuk perekonomian tetapi untuk melestarikan budaya masyarakat lokal

Beberapa kalangan memperkirakan bahwa pariwisata telah mendekati titik jenuh dan telah over exploited (digarap secara berlebihan) sehingga dikhawatirkan akan mulai ditinggalkan oleh wisatawan. Oleh karena itu, muncul upaya pembangunan wisata alternatif yang berkelanjutan sebagai langkah mengantisipasi kejenuhan produk wisata yang telah ada.Wisata alternatif yang diusung adalah pembangunan wisata yang memberi nilai manfaat bagi masyarakat yang disebut Desa Wisata (tourism village).

Pemerintah Provinsi Bali telah menetapkan Peraturan Daerah Nomor 4 tahun 2019 tentang Desa Adat dan pembentukan Dinas pemajuan Masyarakat adat di Provinsi Bali.Desa Adat adalah kesatuan masyarakat hukum adat di Bali yang memiliki wilayah, kedudukan, susunan asli, hak tradisionil dan kekayaan sendiri, tradisi, tata kerama pergaulan hidup masyarakat secara turun temurun dalam ikatan tempat suci (kahyangan tiga atau kahyangan desa) tugas dan kewenanga serta hak mengatur rumah tangganya sendiri. Pengembangan perekonomian adat Bali harus dilakukan dengan prinsip pemeberdayaan sumber daya lokal dan dilakukan secara optimal dan memberikan manfaat yang sebesar-besarnya kepada krama adat. Pemerintah Daerah dan Majelis Desa Adat dapat menfasilitasi pengembangan perekonomian Adat Bali, melalui pembentukan Lembaga Otoritas Perekonomian Adat Bali. Kebijakan investasi asing dalam pengembangan 
pariwisata yang berbasis desa adat merupakan regulasi yang diharapkan mampu berdampak langsung dan dirasakan masyarakat adat.

Berdasarkan uraian di atas, artikel ini merumuskan masalah "Bagaimanakah Kebijakan investasi asing dalam pengembangan pariwisata yang berbasis desa adat di Provinsi Bali?”

\section{KAJIAN LITERATUR}

2.1 Kebijakan Publik.

Dye dalam Islamy (1986:18)

mendifinisikan Kebijaksanaan Negara sebagai "is whatever governmental choose to do or not to do" ( apapun yang dipilih pemerintah untuk dilakukan atau tidak dilakukan). Kebijaksanaan negara meliputi semua tindakan pemerintah; jadi bukan semata -mata merupkan pernyataan keinginan pemerintah. Di samping itu, tindakan yang tidak dilakukan pemerintah juga termasuk kebijakan pemerintah.

Anderson dalam Islamy

menyatakan "Public policies are those policies developed by governmental bodies and officials"( kebijakan Negara adalah kebijaksanaan-kebijaksanaan yang dikembangkan oleh badan-badan dan pejabatpejabat pemerintah).

Implikasi dari kebijaksanaan Negara tersebut adalah sebagai berikut:

a. Kebijaksanaan Negara itu selalu mempunyai tujuan tertentu, atau merupakan tindakan yang berorientasi pada tujuan.

b. Kebijaksaan itu berisi tindakan-tindakan atau pola-pola tindakan pejabat pemerintah.

c. Kebijaksanaan adalah apa yang benar dilakukan oleh pemerintah, bukan merupakan apa yang pemerintah bermaksud akan melakukan sesuatu atau menyatakan akan melakukan sesuatu.

d. Kebijaksanaan negara itu bisa bersifat positif dalam arti tindakan pemerintah mengenai suatu masalah tertentu, atau bersifat negatif yaitu keputusan pemerintah untuk tidak melakukan sesuatu.

e. Kebijaksanaan pemerintah dalam arti positif didasarkan atau berlandaskan pada peraturan perundang-undangan yang bersifat memaksa.

Implementasi dari kebijakan sesungguhnya bukanlah sekedar bersangkut paut dengan mekanisme penjabaran keputusankeputusan politik kedalam prosedur rutin lewat saluran birokrasi, melainkan lebih dari itu, yakni masalah konflik keputusan dan siapa yang memperoleh apa dari suatu kebijakan. Oleh karena itu, impelementasi kebijakan publik adalah proses penting dari keseluruhan proses kebijakan.

2.2. Kewenangan Desa Adat dalam pengelolaan Desa Wisata berdasarkan Perda Nomor 4 tahun 2019 tentang Desa Adat di Bali

Di Bali terdapat dualisme pemerintahan desa yaitu Desa Dinas dan Desa Adat yang memiliki eksistensi yang sama-sama kuat, karena fungsinya dalam masyarakat berbeda. Secara keseluruhan, di Bali saat ini terdapat 1.493 Desa Adat yang tersebar di 9 kabupaten/kota (penjelasan Perda No.4 tahun 2019). Kenyataan saat ini, kedua desa itu posisinya tumpang tindih yang dapat dilihat dari bentuknya sebagai berikut:

a. Satu Desa Dinas mempunyai luas wilayah dan penduduk yang sama dengan Desa Adat seperti Desa Bunutin, Abangsongan, Manik Lui.

b. Satu Desa Dinas meliputi beberapa Desa Adat, seperti Desa Dinas Luwus, dan Mekar sari.

c. Satu Desa Adat terdiri dari beberapa Desa Dinas dan Kelurahan, seperti Desa Adat Denpasar, dan Desa Adat Buleleng.

d. Suatu desa dinas meliputi beberapa desa adat dan sebagian dari desa adat lainnya,seperti kelurahan Ubud terdiri dari enam desa adat yang sepenuhnya di ubud, satu banjar yg berdesa adat di Peliatan. (I Gde Pitana, 1994: h, 140).

Dengan berlakunya Perda Nomor 4 tahun 2019, tentang Desa Adat di Bali yang berlaku mulai tanggal 28 Mei 2019 membuat konsep baru tentang Desa Adat, termasuk di dalamnya tentang pengelolaan desa wisata melalui 
Padruwen Desa Adat yaitu seluruh harta kekayaan Desa Adat yang berifat materiil maupun immaterial. Dalam pengelolaan Padrwen Desa Adat sebagai Desa Wisata dapat dikelola Desa Adat apabila merupakan hak asal usul dan bersekala lokal sebagaimana diatur dalam pasal 25 Perda Desa Adat sebagai berikut:

a. Tempat suci dan kawasan suci;

b. Hutan adat;

c. Sumbersumber air;

d. Padrwen desa adat;

e. Pertanian, perkebunan, perikanan dan peternakan;

f. Pesisir dan segara;

g. Industri pangan dan kerajinan rakyat;

h. Pasar Desa Adat dan tenten;

i. Tambatan perahu;

j. Tempat Permandian umum;

k. Sanggar seni, budaya dan pasraman;

1. Kepustakaan dan taman bacaan;

m. Destinasi dan/atau atraksi wisata; dan

n. Lingkungan pemukiman krama

Berdasarkan uraian di atas, dapat dikemukakan bahwa Desa Adat di Bali memiliki kewenangan yang bersekala lokal dalam pengelolaan Desa Wisata yang didasarkan atas nila adat, agama,t radisi seni dan budaya serta kearifan lokal pada padruwen desa adat yang dalam pengelolaannya melibatkan partisipasi masyarakat desa adat setempat.

\subsection{Kebijakan Investasi Asing Sektor Pariwisata}

Perdagangan bebas antar Negara-negara di dunia telah mengakibatkan meningkatnya volume peredaran uang, meningkatnya aliran penanaman modal khususnya sektor pariwisata.Perubahan- perubahan yang terjadi akibat pengaruh globasisasi ekonomi sangat besar dan perubahan ini bersifat nyata dalam bidang keuangan

Hal ini dikemukakan oleh White dalam Islamy (1984) menyatakan bahwa perubahan yang bersifat nyata dapat dilihat wujudnya dengan terciptanya libralisasi perdagangan yang meningkatkan produk jasa dan barang di sebagian negara-negara di dunia. Perubahan yang bersifat moneter dapat dilihat dari tercapainya kesepakatan antara negara -negara maju untuk menjaga agar stabilitas ekonomi makro di kawasan tertentu dapat terjaga dengan baik.Sedangkan perubahan dibidang keuangan menyangkut terciptanya integrasi pasar keuangan dunia dalam sistem keuangan yang efisien, transparan dan kredible.

Tujuan yang ingin dicapai investor adalah membantu negara penerima modal agar mampu mengatasi kendala perekonomian khususnya bidang permodalan suatu Negara di mana investor melakukan investasi. Dengan investasi diharapkan terbukanya peluang kerja, meningkatnya pendapatan masyarakat agar dapat memenuhi kebutuhan dasarnya, yang nantinya dapat mengangkat mereka dari jurang kemiskinan.

Masuknya investasi asing berperan penting untuk menghindari gap devisa yang defisit pada transaksi berjalan dan juga mampu menggerakkan kegiatan ekonomi yang lesu akibat kurangnya modal bagi pelaksanaan pembangunan ekonomi. Dalam jangka pendek utang luar negeri sangat membantu Pemerintah Indonesia dalam menutupi Anggaran Pendapatan Belanja Negara akibat pengeluaran pembiayaan pembangunan yang sangat besar. Dengan demikian, pertumbuhan ekonomi dapat dipacu sesuai dengan target yang telah ditetapkan.

Kebijakan Investasi asing sektor pariwisata paska pandemi covid 19 belum bisa diandalkan, karena pandemi ini telah membawa kejutan bagi ekonomi global, termasuk Indonesia. Gangguan terjadi pada rantai pasok global, dalam negeri, totalitas pasar keuangan, sektor pariwisata meliputi seluruh mata rantai nilai pariwisata, strategi pengelolaan pariwisata harus diubah dengan mengembangkan produk wisata alternatif sesuai dengan orientasi pasar dan perubahan prilaku wisatawan yang mengedepankan aspek keamanan dan kesehatan. Prilaku wisatawan paska pandemi akan memilih destinasi pariwisata seperti wisata alam, wisata kuliner dan wisata budaya. Tepatlah jika di Provinsi Bali kebijakan investasi asing 
diarahkan pada pengembangan Desa Wisata yang yang berbasis Desa Adat, karena akan berdampak langsung pada peningkatan pendapatan masyarakat, terbukanya kesempatan kerja, dan percepatan pembangunan desa bisa diwujudkan dengan dorongan partisipasi masyarakat.

Pemerintah harus menciptakan iklim innvestasi yang positif dengan melakukan beberapa kebijakan investasi sektor pariwisata sebagai berikut :

a. Melaksanakan debirokratisasi investasi di bidang pariwisata dan deregulasi peraturan yang menghambat investasi.

b. Mengembangkan mekanisme keringanan viskal untuk menarik investasi modal asing di bidang pariwisata.

c. Pemberian insentif investasi di bidang pariwisata yang akan diberikan sesuai dengan ketentuan perundang-undangan.

d. Menyediakan Infrastruktur pariwisata yang memadai.

e. Meningkatkan sinergi promosi investasi dengan instansi terkait di bidang pariwisata.

Pemerintah Provinsi Bali memegang peranan penting dalam aktivitas investasi asing, dilandasi atas penyenggaraan otonomi daerah yang seluas-luasnya memungkinkan untuk menggerakkan investasi di berbagai sektor dan dapat menghasilkan output yang maksimal. Berbagai kebijakan investasi telah dilakukan, seperti menetapakan Peraturan daerah yang meliputi: penyederhanaan perizinan, meringankan pajak dan retrebusi, serta Badan Penanaman Modal Daerah (BKPMD) telah menyelenggarakan pelayanan terpadu satu pintu (PTSP).

\section{METODE PENELITIAN}

Metode penelitian yang digunakan dalam penelitian ini adalah penelitian hukum normatif yaitu penelitian yang mengkaji studi dokumen yakni menggunakan data sekunder seperti peraturan perundang-undangan, teori hukum dari

beberapa pendapat sarjana. Penelitian hukum normatif mengkaji hukum yang dikonsepkan sebagai norma yang berlaku yaitu hukum positip yang dibentuk lembaga perundang-undangan maupun Peraturan Pemerintah, Peraturan Presiden, dan Peraturan Daerah.

\section{PEMBAHASAN}

\subsection{Kebijakan Investasi Asing yang Menjadi Kewenangan Pemerintah Pusat}

Sesuai dengan Undang Undang Nomor 25 tahun 2007 pasal 25 ayat (4) menyatakan Pemerintah menetapkan pelayanan terpadu satu pintu (PTSP) dalam perizinan penanaman modal yang bertujuan untuk membantu penanam modal memproleh kemudahan pelayanan. Untuk mengatur koordinasi kebijakan penanaman modal termasuk perizinannya diserahkan kepada Badan Koordinasi Penanaman Modal (BKPM) pusat.

Adapun kewenangan dari pemerintah pusat sebagai berikut:

a. Penanaman modal yang terkait dengan sumber daya alam yang tidak terbarukan dengan tingkat resiko kerusakan lingkungan tinggi.

b. Penanaman modal pada bidang industri yang merupakan prioritas tinggi pada sekala Nasional dan Daerah

c. Penanaman modal yang terkait fungsi pemersatu dan penghubug antar wilayah atau ruang lingkupnya lintas provinsi;

d. Penanaman modal yang terkait pada pelaksanaan strategi pertahanan dan keamanan nasional;

e. Penanaman modal asing yang berasal dari pemerintah negara lain, bidang penanaman modal lain yang menjadi kewenangan pemerintah menurut undang-undang.

Urusan kebijakan yang menjadi kewenangan pemerintah pusat sebagaimana tersebut di atas dapat diselenggarakan sendiri oleh pemerintah pusat maupun didelegasikan kepada Gubernur sebagai wakil pusat menugaskan kepada pemerintah kabupaten kota.

4.2 Kebijakan Investasi Asing yang Menjadi Kewenangan Pemerintah Provinsi 
Kebijakan investasi/penanaman modal di Provinsi Bali sebagai daerah otonom secara jelas telah diatur dalam Undang Undang Nomor 23 tahun 2014 sebagai perubahan atas Undang Undang Nomor 32 tahun 2004 tentang Pemerintah Daerah dalam pasal 12 ayat (1) menyatakan Pemerintah Daerah menyelenggarakan urusan wajib yang berkaitan dengan pelayanan dasar yang meliputi pendidikan, kesehatan, pekerjaan umum dan penataan ruang, perumahan rakyat dan kawasan pemukiman, ketentraman dan ketertiban umum dan perlindungan masyarakat dan sosial. Dalam ayat (2) Pemerintah Daerah juga mempunyai kewajiban yang tidak berkaitan dengan pelayanan dasar yang terdiri atas 18 butir kewajiban yang didalamnya termasuk kewajiban tentang urusan penanaman modal.

Dalam Undang Undang Nomor 25 tahun 2007 tentang Penanaman Modal ,pengaturan tentang kebijakan penanaman modal oleh Pemerintah Daerah Provunsi diatur dalam pasal 30 yang menyatakan ayat (2): Pemerintah Daerah menyelenggarakan urusan penanaman modal yang menjadi kewenangannya,kecuali urusan penyelenggaraan penanaman modal yang menjadi urusan pemerintah pusat. Ayat (3) Penyelenggaraan urusan pemerintahan di bidang penanaman modal yang merupakan urusan wajib pemerintah daerah didasarkan atas kreteria eksternalitas, akuntabilitas, dan efisiensi pelaksanaan kegiatan penanaman modal. Ayat (5) penyelenggaraan penanaman modal yang ruang lingkupnya lintas kabupaten/kota menjadi urusan pemerintah provinsi.

Dalam rangka melaksanakan maksud ketentuan diatas diatur dalam Peraturan Presiden Nomor 27 tahun 2009 tentang Pelayanan terpadu satu pintu (PTSP) oleh Pemerintah Propinsi. serta dipertegas dengan Peraturan BKPM Nomor 12 tahun 2009 tentang Tata cara, pembinaan dan pelaporan PTSP di bidang penanaman modal. Dari paparan ketentuan diatas Kebijakan Penanaman Modal Asing oleh Pemerintah Propinsi Bali secara atribusi diberikan kepada Gubernur.Sebagai tindak lanjut dari kenetuan dimaksud Perintah Provinsi Bali telah menetapkan Peraturan Daerah Nomor 1 tahun 2016 tentang pemberian insentif dan/atau kemudahan kepada masyarakat dan/atau penanam modal. Dalam pasal 3 ayat (1) menyatakan Gubernur dapat memberikan insentif dan/atau kemudahan kepada masyarakat dan/atau penanam modal yang baru memulai kegiatan penanaman modal baru dan/atau perluasan penanaman modal Dalam ayat (3) menyatakan pemberian insentif kepada penanam modal, meliputi pengurangan, keringanan dan pembebasan pajak daerah. Pengurangan dan, keringanan atau pembebasan retrebusi daerah.

\subsection{Kebijakan Investasi Asing yang Menjadi Kewenangan Pemerintah Kabupaten/Kota}

Dalam Undang-Undang Nomor 25 tahun 2007 tentang penanaman modal, kewenangan Pemerintah Daerah Kabupaten/Kota dalam kebijakan investasi asing diatur dalam pasal 30 ayat (6) yang menyatakan penyelengaraan penanaman modal yang ruang lingkupnya kabupaten/kota menjadi urusan kabupaten kota. Dalam rangka melaksanakan maksud ketentuan dimaksud, maka diatur lebih lanjut dalam Peraturan Presiden RI Nomor 27 tahun 2009 dan Peraturan Kepala BKPM Nomor 12 tahun 2009 tentang Tata cara pelaksanaan pembinaan, dan pelaporan pelayanan terpadu satu pintu oleh Pemerintah Kabupaten/Kota (pasal 7 dan 8).

Dalam Undang Undang Nomor 23 tahun 2014 tentang Pemerintah Daerah secara implisit diatur kebijakan investasi asing /penanaman modal yang menjadi kewenangan pemerintah kabupaten/kota, diatur dalam pasal 12 ayat 1 dan 2, yang meliputi 18 jenis urusan wajib di luar urusan pelayanan dasar termasuk penanaman modal. Secara delegasi Bupati/Walikota memiliki kewenangan untuk menetapkan peraturan/kebijakan investasi asing yang telah dilimpahkan oleh Kepala Badan Koordinasi Penanam Modal Pemerintah Kabupaten/Kota di Bali telah menetapkan Peraturan Daerah tentang kebijakan investasi di daerahnya, misalnya Kota Denpasar melalui Peraturan Wali Kota Nomor 1 tahun 2017 tentang penyelengaaraan pelayanan 
perijinan dan non perijinan termasuk perijinan penanaman modal.

\subsection{Kebijakan Investasi Asing dalam Pengembangan Pariwisata yang Berbasis Desa Adat di Provinsi Bali}

Dengan ditetapkannya berbagai kebijakan investasi dalam bentuk tindakan dan peraturan perundang-undangan maka kedepan Pemerintah Provinsi Bali secara normatif perlu membentuk Peraturan Daerah yang khusus memberi kewenangan kepada Desa Adat untuk mengembangkan desanya menjadi Desa wisata dengan bantuan investasi asing.

Pengembangan pariwisata yang berbasis desa adat sangat positif untuk lingkungan fisik dan alam, sosial budaya dan ekonomi. Dampak pariwisata terhadap fisik dan alam akan terjaga dan terpelihara kebersihan dan kenyaman lingkungan. Kedua dampak terhadap kehidupan sosial dan budaya yaitu terpeliharanya bangunan-bangunan yang bernilai budaya dan terpeliharanya kebudayaan tradisional seperti seni tari dan adat tradisional dan sekaligus berdampak terhadap pendidikan baik formal maupun non formal.Dampak yang lain terbukanya lapangan pekerjaan baru, meningkatkan taraf hidup karena meningkatnya pendapatan masyarakat dan juga membantu percepatan pembangunan sarana dan prasarana di desa.

Model Kebijakan investasi asing dalam pengelolaan desa adat menjadi desa wisata secara umum telah diatur dalam Undang Undang 25 tahun 2007 tentng penanaman modal asing,Undang Undang Nomr 23 tahun 2014 tentang Pemerintah Daerah,serta Peraturan Presiden Nomor 27 tahun 2009 tentang Pelayanan Terpadu Satu Pintu (PTSP),Perda Nomor 1 tahun 2016 tentang pemberian insentif dan/atau kemudahan kepada masyarakatdan/atau penanam modal, serta Perda Nomor 4 tahun 2019 tentang Desa Adat Bali yang pada dasarnya bertujuan untuk mengembangkan perekonomian Desa Adat yangdisusun dalam rencana strategis yaitu Rencana Anggaran dan Pendapatan Belanja Desa Adat.
Kebijakan sebagai tindak pemerintah adalah didasarkan kewenangan yang dimiliki untuk mengisi kekosongan hukum. Kebijakan investasi asing dalam pengembangan pariwisata yang berbasis desa adat,diperlukan demi adanya kepastian hukum. Turut sertanya investasi asing sangat memungkinkan dilakukan atas inisiatif desa adat yang ingin mengembangkan pengelolaan pariwisat perlu ditetapkan pengaturan yang bersifat khusus oleh Pemerintah Provinsi, Kabupaten/kota dan Desa adat dan dapat memilih ketetapan hukum yang sesuai dengan peran yang diinginkan yang disebut Kebijakan.

Dibentuknya peraturan investasi oleh Pemerintah Provinsi, diharapkan terbangun jalinan yang harmonis antara Pemerintah Pusat, Pemerintah Daerah, investor asing dan masyarakat desa adat, dalam pengembangan pariwisata yang berbasis desa adat. Pemerintah Provinsi dan kabupaten/kota dapat menetapkan Peraturan Daerah berdasarkan asas desentralisasi dan tugas pembantuan, dan Desa Adat melalui kedudukannya memiliki otonomi, di Bali disebut konsep Tri Hita Karana dapat menetapkan aturan yang dibuat Desa Adat disebut Awig-awig dengan tetap berpedoman pada prinsip-prinsip penyelenggaraan pemerintahan yang baik.

\section{PENUTUP}

Pemerintah perlu melakukan stratgistrategi dalam meningkatkan minat investor agar mau menanamkan modalnya pada sektor pariwisata. Secara implesit pengaturan tentang penanam modal asing tercantum dalam Undang Undang Nomor 25 tahun 2007 tentang penanaman modal yang dapat dilaksanakan oleh pusat maupun daerah. Dalam Undang-Undang nomor 23 tahun 2014 tentang Penerintah Daerah dinyatakan pula bahwa pemerintah daerah dapat menyelenggarakan urusan wajib diluar kewajiban pelayanan dasar termasuk penanaman modal.

Kewenangan Desa Adat di Provinsi Bali diatur dalam Peraturan Daerah Nomor 14 tahun 
2019 tentang Desa Adat yang memuat konsep padruwen desa adat dapat dikembangkan pengelolaannya sebagai Desa Wisata. Desa Adat memiliki kewenangan yang bersekala lokal dalam pengelolaan desa wisata yang didasarkan atas nilai-nilai adat, agama, tradisi, seni dan budaya serta kearifan lokal dengan melibatkan partisipasi masyarakat adat.

Kebijakan investasi asing dalam pengembangan pariwisata berbasis adat di Provinsi Bali perlu ditetapkan dalam kebijakan hukum secara khusus agar mampu mengatasi kekosongan hukum serta dapat menjamin kepastian hukum bagi kepentingan investor dan masyarakat. Pemerintah Daerah Provinsi Bali, Kabupaten/Kota dan Desa Adat dapat mengambil peran sesuai kedudukan dan kewenangannya sehingga terbangun hukum investasi yang efektif, efisien dan akuntable yang berdasarkan asas legalitas serta prinsipprinsip penyelenggaraan pemerintahan yang baik

Investasi asing dapat berlangsung untuk waktu jangka panjang. Untuk itu, Pemerintah Daerah dapat mengembangkan spesifikasi daya tarik investasi dan kemudahan-kemudahan yang tidak dimiliki oleh daerah lain, di samping faktor setabilitas politik dan keamanan.

Pemerintah Daerah Provinsi Bali perlu segera menetapkan Peraturan Daerah secara khusus, untuk meningkatkan penanaman modal dan prosedur perizinan yang tidak menyulitkan investor.

\section{DAFTAR PUSTAKA}

Bagir, Manan. 2001. Menyongsong Otonomo Daerah. Jogjakarta: Pusat studi hukum, Universitas Gajah Mada.

Hadjon, Philipus M. 1998. Pengantar Hukum Administrasi Indonesia. Jogjakarta: Universitas Gajah Mada University Press.

Hefrijani, Pontolawikang. 2016. Kajian Yuridis UU Nomor 25 tahun 2007 tentang Penanaman modal pada Pemerintah Daerah Provinsi dan
Kabupaten/Kota. Jurnal Lex Administratum,Vol.4, Nomor 1.44

Hikmahanto, Juwana. 2003. "Liputan Investasi Indonesia”. Jakarta: Seleksi Tahunan Investasi Indonesia.

Irfan, Islamy.1984. Prinsip-Prinsip Perumusan Kebijaksanaan Negara. Jakarta: Penerbit Bina Aksara.

Rahmadi, Supanca Ida Bagus. 2006. Kebijakan Hukum dan Kebijakan Investasi Langsung di Indonesia, Ghalia Indonesia, Ciawi-Bogor.

Reinheart, Monopo. 2017. "Peranan Pemerintah dalam mempengaruhi Penanaman Modal di Sektor Pariwisata". Lex Administratum. vol.v/ N0.4/Jun/2017.

Pitana, I G. dan Gayatri P.G. 2005). Sosiologi Pariwisata. Yogyakarta: Penerbit Andi.

Undang Undang Nonor 25 tahun 2007 tentang Penanaman Modal.

Undang Undang Nomr 23 tahun 2014 tentang Pemerintah Daerah.

Peraturan Presiden Nomor 27 tahun 209 tentang Pelayanan Terpadu Satu Pintu.

Peraturan Kepala Badan Koordinasi Penanaman Modal Nomor 14 t1hun2015 tentang Pedoman dan Tata Cara Izin prinsip Penanaman Modal.

Perda Provinsi Bali Nomor 1 Tahun 2016 tentang pemberian insetif dan/atau kemudahan kepada masyarakat dan/atau penanaman modal.

Dinas Penanaman Modal dan Perizinan Terpadu Satu Pintu. "Realisasi PMDN dan PMA di Provinsi Bali Tahun 2019". (diunduh tanggal 6 Mei 2021).Tersedia dari :https://www.lapor.go.id. 
BPS Provinsi Bali. "Penanaman Modal Asing di Provinsi Bali" (diunduh tanggal 6 Mei 2021).Tersedia dari: https:// bali.bps.go.id.

Peraturan Daerah Provinsi Bali Nomor 4 tahun 2019." Desa Adat di Bali”(diunduh tanggal 14 juni 2019). Tersedia dari: https://jdih.baliprov.go.id 